Eszter Zelenka (Boedapest):

\title{
Het gebruik van vaste verbindingen tijdens examens 'tolken'
}

\section{Inleiding}

Motto: 'De contrastieve analyse van vaste woordverbindingen (vw's) waarbij meestal taalvormen van een vreemde taal met die van de moedertaal vergeleken worden, is een terrein dat gekenmerkt wordt door een speciale wisselwerking tussen theorie en praktijk. Op het praktische gebied bevinden zich de bekende problemen die zich voordoen bij het onderwijzen van een vreemde taal, het tolken en vertalen, en het redigeren van een woordenboek.' (Citaat uit Erzsébet Mollay’s lezing op het Tiende Colloquium Neerlandicum in 1988 (Mollay 1989))

Toen ik in 1986 begonnen was met mijn studie Nederlands, leerde ik Erzsébet Mollay als hoofd van de vakgroep Neerlandistiek kennen. Zij was een bevlogen taalleraar, een geëngageerde docente die zich altijd grondig en accuraat voorbereidde op haar colleges. Zij was niet de meest populaire docent bij de studenten, ze streefde daar ook nooit naar. Ze genoot echter wel veel respect, iedereen wist dat we het bestaan van de vakgroep Neerlandistiek - in die tijd nog een deel van de vakgroep Germanistiek-Romanistiek - aan haar te danken hadden. Een aantal jaren later, toen wij in 1991 collega's werden, leerde ik Erzsébets vriendelijke, begrijpende kant kennen. Toen ik haar voor het laatst in 2015 ontmoette, om een interview te maken met haar voor een onderzoek, ontving ze me bij haar thuis met zelfgemaakt gebak en bij het afscheid moest ik walnoten uit haar tuin meenemen om ze aan mijn kinderen te geven.

In het tweede jaar van mijn studie gaf Erzsébet colleges taalverwerving en grammatica aan onze groep. Tijdens haar colleges vestigde ze de aandacht op collocaties, vaste verbindingen en spreekwoorden. Haar onderzoek ging dan ook over vaste verbindingen, ze kon er bevlogen over vertellen. In dat jaar gaf ze een presentatie op het Tiende Colloquium Neerlandicum, waarin ze stelde:

'De impuls tot contrastieve studie van Nederlandse en Hongaarse vaste woordverbindingen kreeg ik uit de onderwijspraktijk. Mijn onderzoek is op de praktijk gericht, natuurlijk op het nut voor het leren van het Nederlands als vreemde taal, het tolken en vertalen en het redigeren van een (gepland) Nederlands-Hongaars handwoordenboek.' (Mollay 1989:179 v.)

Uit dankbaarheid voor, en als eerbetoon aan haar werk als docent en wetenschapper heb ik besloten om onderzoek te doen naar het gebruik van vaste verbindingen bij mijn studenten, de 'tweede generatie' neerlandici. Mijn impuls tot contrastieve studie komt dus door Erzsébet en stoelt op mijn eigen onderwijspraktijk. Het doel van dit onderzoek is dan ook om inzicht te krijgen in het gebruik van collocaties om later meer aandacht te kunnen vestigen op het onderwijzen ervan. 
Derdejaars studenten Nederlands aan de Károli Universiteit kunnen een semester lang het vak tolken als keuzevak volgen. Het gaat hier niet om een volledige tolkopleiding, studenten krijgen slechts een voorproefje van wat het beroep tolken kan inhouden. Tijdens de colleges tolken oefenen de studenten tolken uit het Nederlands naar het Hongaars en andersom. Aan het eind van het semester leggen studenten een mondeling examen af: hun eerste taak is om een twee-minutenlange tekst uit een Nederlandstalige video naar het Hongaars te tolken, vervolgens krijgen ze een korte Hongaarstalige, geschreven tekst die ze naar het Nederlands moeten '(ver)tolken'. In deze bijdrage ga ik me slechts met de tweede opdracht bezighouden. De reden waarom ik mijn experiment juist hierover uitvoer is dat het vinden van de juiste collocatie in een vreemde taal vaak problemen oplevert en ik was ernaar benieuwd in hoeverre de derdejaars studenten in staat waren collocaties op een correcte manier te gebruiken in een stressvolle situatie, zoals tolken.

In mei 2019 heb ik de tolkexamens op audio opgenomen. Uit analyse van het opgenomen materiaal blijkt welke lexicale, grammaticale en cultuurspecifieke moeilijkheden studenten bij het begrijpen en tolken van de teksten ondervinden. In sectie 5 ga ik specifiek in op het gebruik van collocaties tijdens het proces van tolken.

\section{2 À vue-tolken}

In dit experiment werd studenten gevraagd om een Hongaarse tekst à vue naar het Nederlands te tolken. À vue-tolken is een type opdracht dat tijdens het college regelmatig aan bod kwam. Waarom juist deze vorm van tolken en waarom tolken naar het Nederlands, de doeltaal, en waarom niet naar het Hongaars, de moedertaal? In het werk van culture bemiddelaars zoals tolken, komt het vaak voor dat een bepaald stuk geschreven tekst mondeling, even snel naar de andere taal vertaald moet worden: bij zakelijke besprekingen, voor de rechtbank, in het ziekenhuis, in de media of in privé situaties gebeurt dit geregeld (F. Csizmazdia 2020:38; Veresné Valentyini 2020:123). De meeste studenten die een semester tolken gevolgd hebben zullen later geen opdrachten kunnen uitvoeren als simultaantolk - die altijd naar hun moedertaal tolken -, daarvoor zouden ze nog een extra opleiding moeten volgen. In de bovengenoemde situaties zullen ze echter in beide richtingen moeten kunnen tolken, naar mijn ervaring vaak à vue. Omdat mijn studenten geacht worden tussen B1 en B2 van het ERK te zitten, heb ik een brontekst gekozen die qua moeilijkheidsgraad bij hun niveau paste: het is een kort Hongaarstalig krantenartikel dat een relatief makkelijk boodschap op een objectieve manier doorgeeft. De boodschap is duidelijk, men hoeft niet tussen de regels te lezen, de structuur van de tekst is voorspelbaar - hiermee kan de niettalige moeilijkheidsgraad van de tekst geminimaliseerd worden. 
De Hongaarse tekst die de studenten moesten tolken staat in de bijlage (8), hieronder staat de Nederlandse vertaling met verschillende mogelijke vertaaloplossingen:

Hoeveel planeten (aardbollen) zouden we nodig hebben/hebben we nodig als iedereen zou willen leven zoals jij? / als we iedereen een leven zouden gunnen zoals dat van jou? / om iedereen te kunnen laten leven zoals jij?

Wij mensen leven van (datgene) wat de natuur ons biedt. Maar als de hele wereldbevolking zou leven zoals de Europeanen / Maar als mensen er overal ter wereld dezelfde levensstijl op na zouden houden als wij hier in Europa, / Maar als men overal ter wereld zou leven zoals wij hier in Europa, dan zouden we al op 10 mei as. de datum bereiken waarop het totale verbruik van de mensheid het niveau zou overschrijden van wat de aarde in één jaar kan produceren en/of incasseren/ verwerken.

Het Global Footprint Network publiceert elk jaar de actuele/nieuwe datum van de werelddag van de overconsumptie /de nieuwe datum van de globale overconsumptie, die vorig jaar op 1 augustus viel.

\section{Definities en de rol van collocaties}

Er bestaan verschillende wetenschappelijke definities van vaste verbindingen, fraseologismen, collocaties en idiomen. Voor pedagogische doeleinden, voor het leren van een vreemde taal zijn deze vaak niet relevant. De brede definitie die door Piet de Kleijn wordt gebruikt ten behoeve van vreemdetaalleerders kan echter de weg wijzen in het oerwoud van uiteenlopende definities. Om de essentie en het belang van het leren en gebruiken van vaste verbindingen te begrijpen stelt De Kleijn:

'Ik houd het hier op de wat vage, algemene term vaste verbinding, en versta daaronder dat een bepaald woord uitsluitend of bij voorkeur voorkomt in combinatie met een of meer andere woorden'. (Kleijn 1988)

Bij het leren van een vreemde taal, bij het verwerven van vocabulaire is het essentieel dat leerders ook de omgeving van een woord herkennen en het woord in een correcte zin leren produceren en gebruiken. Hiervoor moeten ze ook over informatie beschikken over de concrete woorden waarmee een bepaald woord gecombineerd kan worden:

'Knowing a word also includes an appreciation of the restrictions on use of words and collocational patterns, that is, the other words they associate with.' (Herschensohn en Young-Scholten 2013:445)

Siyanova-Chanturia en Spina (2015) stellen dat vaste verbindingen 
'have been found to constitute $20 \%$ to $50 \%$ of spoken and written native-speaker discourse $[\ldots]$ four such units are produced by a native speaker in every minute of spoken discourse. Clearly, such estimates suggest that knowing and using a wide range of units above the word level is an essential characteristic of mature linguistic competence.' (p. 538)

González-Fernández en Schmitts (2015) onderzoek stelt dat 'Productively the lack of use of collocations, as well as the over-, under- or mis-use of them lead to L2 speakers being judged as odd, unnatural or non-nativelike.' (p. 97)

Volgens De Bot et al. (2005) is het voor leerders een ware uitdaging om te leren welke woorden of woordsoorten we samen met een woord moeten gebruiken, welke woorden of welk woordsoort we vóór of na een bepaald woord kunnen verwachten. Nesselhauf (2003) vindt dat leerders meestal geen probleem hebben met het begrijpen van collocaties, ze struikelen echter over het gebruik ervan.

Als we ernaar streven om onze studenten native-like taalgebruik aan te leren, moeten we extra aandacht schenken aan het leren en inzetten van vaste verbindingen tijdens het leerproces. Des te meer geldt dit voor tolken, waar we native-like, goed ontwikkelde linguïstische competentie verwachten in de vreemde taal.

\section{Deelnemers, methode}

Aan het onderzoek namen derdejaars studenten Nederlands van de Károli Universiteit deel, die tijdens het voorjaarssemester in 2019 colleges tolken volgden. Zeven studenten Nederlands namen deel aan de colleges en het onderzoek. Hun taak op het examen was om een Hongaarse tekst van 98 woorden á vue naar het Nederlands te vertalen. De studenten kregen de tekst in handen, ze mochten het één keer doorlezen en daarna moesten ze beginnen met tolken.

De twee onderzoeksvragen waarop ik een antwoord zocht tijdens het onderzoek, waren de volgende:

1. In hoeverre gebruiken studenten vaste verbindingen tijdens het uitvoeren van een tolkopdracht?

2. In hoeverre komt hun gebruik van vaste verbindingen overeen met dat van een moedertaalspreker?

Ik heb de opdrachten op audio opgenomen, de teksten letterlijk uitgeschreven. Om vraag 2 te kunnen beantwoorden heb ik een Nederlandstalige collega, Cora-Lisa Sütő gevraagd om de tekst van de opdracht te vertalen naar het Nederlands om een voorbeeld te hebben hoe een moedertaalspreker de tekst zou kunnen tolken.

Daarna heb ik gekeken waar de moedertaalspreker vaste verbindingen gebruikte en ging ik na of de studenten dat ook hadden gedaan. De Nederlandse 
vertaling van de tekst bevat tien vaste verbindingen. Voor de volledige teksten zie Bijlage 1.

\section{Bespreking}

\subsection{De titel}

Hoeveel planeten hebben we nodig / zouden we nodig hebben als iedereen zou willen leven zoals jij?

In de titel zien we één collocatie, met name nodig hebben voor de vertaling van 'kellene hozzá'. Het Hongaarse werkwoord staat in de voorwaardelijke wijs, naar het Nederlands vertaald in de onvoltooid tegenwoordige tijd (o.t.t.) of de onvoltooid verleden toekomende tijd (o.v.t.t.). Bij de vertaling van de studenten zien we de o.v.t.t. in twee gevallen terug: zouden we nodig hebben en zouden ervoor nodig zijn. In alle andere gevallen wordt de o.t.t. gebruikt in de combinatie met moeten hebben, nodig zijn (2 keer), nodig hebben. Eén student gebruikt foutief het werkwoord hoeven en één student geeft geen vertaling van de titel.

Bij de vertaling van nodig hebben beseffen vijf van de zeven studenten die de titel vertaalden dat ze een collocatie kunnen gebruiken.

\subsection{Zin 1}

Wij mensen leven van (datgene) wat de natuur ons biedt

Voor de vertaling van 'abból élünk' zien we zes keer de combinatie leven van, dezelfde combinatie die door de moedertaalspreker gebruikt werd. Eén student geeft als vertaling leven waarvoor en één student struikelt over de vertaling. Ze gebruikt de combinatie leven vanuit maar na enige aarzeling roept ze 'Pffff' en geeft het tolken van deze zin op. Dit is een interessant geval: het laat zien dat de student in de war wordt gebracht door het niet kunnen vinden van het passende vaste voorzetsel. Ze geeft dus aan dat ze weet dat er een combinatie is, maar ze kan het op dat moment niet oproepen. Ze verliest haar geduld, geeft op en stopt hier met de zin, met het uitvoeren van de taak.

\subsection{Zin 2 - Deel 1}

Maar als mensen er overal ter wereld dezelfde levensstijl op na zouden houden als wij hier in Europa

In het eerste deel van zin 2 herkennen vijf van de zeven studenten dat er een vaste verbinding gebruikt kan worden: ter wereld, in de wereld en driemaal op de 
wereld wordt er gebruikt. Drie studenten geven geen vertaling van dit zinsdeel. Weliswaar zijn hun zinnen zonder de vertaling van deze plaatsbepaling ook begrijpelijk, toch wordt er bij een tolkopdracht verwacht dat de tolk zoveel mogelijk informatie van de brontekst in de doeltekst doorgeeft en geen zinsdelen weglaat. Deze omissie is naar mijn mening niet zo zeer te wijten aan de gebrekkige taalkennis van de studenten, maar eerder aan het gebrek aan praktijkervaring met tolkvaardigheden.

De moedertaalspreker gebruikt in haar vertaling de combinatie men(sen) overal ter wereld. Van de studenten is er maar één die ter wereld zegt, de andere studenten geven de voorkeur aan de veel frequentere preposities in en op, terwijl ze de vorm ter wereld passief zeker moeten kennen. Maar wegens de vreemde, oudere morfologische vorm is het voor vreemdetaalleerders geen vanzelfsprekende keuze, in tegenstelling tot de meer transparante moderne vorm van prepositie opgevolgd door een lidwoord.

In het tweede deel van zin 2 komt het één keer voor dat een student dit zinsdeel niet vertaalt. Eén student gebruikt geen vaste verbinding, maar de combinatie leven als. De moedertaalspreker geeft het werkwoord leven ook als optie aan, maar dan gevolgd door zoals, en niet door als. De andere studenten geven allemaal verschillende oplossingen met een substantief gevolgd door een werkwoord. Eén student vertaalt dit zinsdeel met leven volgen, een andere met leven hebben. Alle andere doen een poging om, net als in het Hongaars, een samengesteld substantief te combineren met een werkwoord. Eén student geeft een letterlijke vertaling *een levensmethode hebben. Hiernaast komen nog oplossingen als, levensstijl volgen/leven/hebben en levenspatroon volgen voor. De omschrijving op die manier kan leven komt één keer voor.

De elegante oplossing, de combinatie een levensstijl eropna houden, die door de moedertaalspreker wordt voorgesteld als vertaling van de Hongaarse collocatie 'életmódot folytat', is niet bekend bij de studenten. Het werkwoord eropna houden is een laagfrequente combinatie, volgens woorden.org heeft het twee mogelijke spellingsvormen (erop nahouden en eropna houden). Het online Van Dale woordenboek biedt alleen de vorm eropna houden aan. Werkwoorden waar het woordje er deel van uitmaakt, veroorzaken altijd moeilijkheden voor vreemdetaalleerders. Omdat het deel met er geen duidelijke betekenis heeft, wordt het vaak weggelaten of komt het op de verkeerde plaats terecht in de zin. Bovendien hoort men het woordje er in gesproken taal niet, het wordt weggeslikt, waardoor het leren van het correcte gebruik nog meer bemoeilijkt wordt.

Studenten doen hun best om een complexe zin te vertalen en, op zoek naar collocaties en vaste verbindingen, kiezen ze meestal combinaties die minder ingewikkeld zijn. Vaak blijkt dat de gekozen combinaties dan ook minder passend of incorrect zijn (in Bijlage 2 worden de niet acceptabele collocaties met een * aangemerkt). Durrant en Schmitt (2015) stellen dat 'even quite advanced learners tend not to know much formulaic language. This forces them to piece structures together word-by-word in ways that they can only hope will prove acceptable' (p. 
158). Ze stellen ook vast dat minder frequente combinaties door leerders worden onderbenut, mede omdat: 'low frequency of occurrence simply means that such collocations are likely to be acquired later than other parts of nativelike phraseology' (p.157).

We kunnen ook veronderstellen dat derdejaars studenten het laagfrequente werkwoord eropna houden nog niet hebben verworven en de collocatie er een levensstijl op nahouden niet kunnen produceren. Het moeilijke bij het aanleren van dit soort transparante, makkelijk begrijpelijke collocaties is dat ze bij de receptieve vaardigheden (lezen en luisteren) geen struikelblok vormen, in tegenstelling tot combinaties waarvan de betekenis ontcijferd moet worden (bv. de kool en de geit sparen, het zwarte goud). De betekenis van de combinatie er een levensstijl op nahouden is voor studenten op dit niveau receptief meteen duidelijk. Daarom valt het ze vaak niet op dat ze een collocatie als deze uit het hoofd zouden moeten leren en oefenen om het vervolgens correct te kunnen gebruiken. Bij het lesgeven op hogere niveaus wijzen docenten hun studenten er regelmatig op dat ze aandacht moeten besteden aan een vaste combinatie, anders zien ze het makkelijk over het hoofd. Blijkbaar is dit niet voldoende om actieve kennis te bereiken. Het inoefenen van moeilijkere structuren en het activeren van passieve woordenschat is een van de belangrijkste taken van het taalonderwijs op hogere niveaus. Studenten van niveau B2 of C1 begrijpen doorgaans de betekenis van collocaties, ze herkennen ze ook, maar de stap naar actief gebruik vergt nog meer aandacht. Dit moet dan ook in het focus staan van verdere woordenschatuitbreiding.

\subsection{Zin 2 - Deel 2}

dan zouden we al op 10 mei as. de datum bereiken waarop ...

In de Hongaarse zin staat het overgankelijk werkwoord 'átlép', in de betekenis van 'over iets heen stappen/lopen'. Bij gebrek aan inzetbare collocatie, zoals de 'datum bereiken/overschrijden' gebruiken de studenten de werkwoorden lopen, doorlopen, overlopen, stappen, toetreden en overslaan in hun vertaling. Opvallend is dat ze van deze Nederlandse werkwoorden allemaal overgankelijke werkwoorden maken, bv. *de datum toetreden, *de datum stappen, *de datum doorlopen, etc. Eén van de studenten geeft geen vertaling, en één student gebruikt het werkwoord bereiken, zoals de moedertaalspreker. Dit is een pregnant voorbeeld van hoe sterk en makkelijk de achterliggende grammaticale informatie van een woord uit T1 naar T2 wordt getransfereerd: het Hongaarse werkwoord is overgankelijk en de studenten aarzelen niet om deze eigenschap op de Nederlandse werkwoorden te projecteren. Het is ook opmerkelijk dat de studenten zich vastklampen aan het aspect van bewegen en lopen: blijkbaar kleeft dit beeld, deze metafoor van 'een stap zetten' zo sterk aan de betekenis van de zin dat de studenten het niet los kunnen laten. Het werkwoord overschrijden is 
hoogstwaarschijnlijk niet bekend bij de studenten, daarom proberen ze de andere, onovergankelijke werkwoorden van beweging in de T2 te gebruiken. Hoewel ze het werkwoord bereiken moeten kennen, blijven de meesten in het woordveld van ‘lopen/bewegen/een stap zetten’ zoeken naar een passende vertaling.

\subsection{Zin 2 - Deel 3}

het niveau zou overschrijden van wat de aarde in één jaar kan produceren - túllépi azt a szintet

Het werkwoord overschrijden, een letterlijke vertaling van het Hongaarse werkwoord 'túllépi' is niet bekend bij de studenten, het is dan ook een laagfrequent woord, studenten moeten zich met andere woorden behelpen. Hier zien we opnieuw dat het Hongaarse werkwoord in de collocatie het element 'stappen/lopen' bevat, het aspect van beweging vinden we dan ook terug in de vertalingen: *een niveau doorgaan, *met het niveau overgaan/doorslaan. Dit zijn helaas geen geslaagde, correcte vertalingen, maar de studenten deden een poging om het aspect van beweging terug te geven in hun vertaling. Dit blijkt het moeilijkste zinsdeel in de hele tekst, twee studenten geven helemaal geen vertaling hier, en twee andere willen het combineren met het hieropvolgende zinsdeel, maar dan zonder succes.

\subsection{Zin 3}

Global Footprint publiceert elk jaar de actuele/nieuwe datum van de werelddag van de overconsumptie /de nieuwe datum van de globale overconsumptie, die vorig jaar op 1 augustus viel.

Het werkwoord publiceren is hier een vertaling van de Hongaarse collocatie 'nyilvánosságra hoz', letterlijk 'publiek/openbaar maken'. Wat we hier zien is een bijzonder facet van vertalen: in de brontaal staat een collocatie en de vertaler of tolk zoekt in zijn geheugen naar een collocatie in de doeltaal, terwijl het niet nodig zou zijn om er een te gebruiken, er bestaat namelijk een werkwoord in de doeltaal die de betekenis van de collocatie uit de originele tekst dekt. In deze zin geven drie studenten een vertaling met het werkwoord publiceren, anderen komen met vertalingen waarbij ze collocaties gebruiken als de datum bekend maken, *de datum (van de werelddag) brengen, *een rapport geven over en *in publici nemen.

Helaas is het creëren van een collocatie in een andere taal onbegonnen werk, qua opbouw lukt het de studenten wel om collocatieachtige combinaties te produceren, maar uiteindelijk zijn dit geen bestaande combinaties en leveren de vertalingen geen correcte Nederlandse zinnen op. 
In zin 3 komen we twee keer een combinatie met het woord jaar tegen: elk jaar en vorig jaar. Het meest opmerkelijke bij de vertaling van deze woordcombinatie is het meermalige, verkeerde gebruik van het woordgeslacht, met name het gebruik van de verkeerde vorm van het adjectief: *in elke jaar, *iedere jaar, *elke jaar en *vorige jaar komen voor naast de correcte vormen elk/vorig jaar en in het vorige jaar. Ik was heel erg verbaasd over het foutieve gebruik van het adjectief bij zo'n hoogfrequent woord, dat studenten al in de allereerste Nederlandse les geleerd hadden. Ik besloot om een onderzoekje te doen om te kijken waar de bron van het foutieve gebruik kan liggen. Een paar weken na het examen tolken legde ik de studenten een lijst van tien substantieven voor, waarbij ze het correcte lidwoord moesten opschrijven. Deze toets heb ik aan vijftien studenten gegeven, derdejaars- en eerste masterstudenten, waaronder de zeven studenten die het tolkexamen gedaan hadden. Bij het woord jaar hebben dertien van de vijftien studenten het correcte lidwoord kunnen opschrijven.

De vraag dringt zich op waarom de studenten dan tijdens het examen over het gebruik van zo'n makkelijke, goed gekende, frequente combinatie struikelden. De meest voor de hand liggende verklaring is dat presteren onder druk - en bij tolkopdrachten staat men in ieder geval onder tijdsdruk - tot verslechterde cognitieve prestatie leidt (Hein en Verlangen 2020). Studenten moeten en willen in een redelijk hoog tempo tolken en naast het ophalen van de juiste woorden en het verwerken en formuleren van zinnen in de doeltaal blijft er geen cognitieve capaciteit meer over om op het juiste genus te letten. Onder tijdsdruk is ook de kans groter dat er overgeneralisatie optreedt: de meeste Nederlandse substantieven hebben de als lidwoord, waarschijnlijk vervult de de rol van het prototypische lidwoord. Een andere mogelijke verklaring is dat Hongaarstalige studenten in wier moedertaal er geen genusverschillen bestaan, in een stressvolle tolksituatie geen of minder aandacht besteden aan - vanuit het perspectief van hun moedertaal bekeken - zo'n weinig relevant vraagstuk als genus. Op het moment dat hun aandacht erop wordt gericht - zoals bij de opdracht waarbij het juiste lidwoord moest worden geproduceerd - kunnen ze wel het juiste antwoord geven.

\section{Conclusie}

Uit het opgenomen materiaal blijkt dat bij tolken uit de moedertaal:

a) de grammaticale eigenschappen van de brontaal een invloed uitoefenden op de gemaakte woordkeus en vice versa;

b) de studenten vaak geconfronteerd werden met verwerkingsproblemen als ze zich aan een redelijk tempo wilden houden (het jaar wordt door de tijdsdruk *de jaar);

c) wegens het gebrek aan goed geoefende tolkvaardigheden en compensatiestrategieën te moeilijke zinsdelen weggelaten werden - een aspect dat niet acceptabel is in een authentieke tolksituatie. Zoeken naar 
goede oplossingen kost zoveel energie en tijd dat het uiteindelijk in weglating resulteert bij onervaren studenten.

Verder bleek uit het materiaal dat studenten, die over het algemeen hogere cijfers haalden voor taalverwervingsvakken een frequenter, correcter gebruik van vaste verbindingen vertoonden en meer vertaaloperaties uitvoerden dan studenten met minder goede studieresultaten (Csizmadia 2020).

Als we naar de opgenomen data kijken, kunnen we concluderen dat de studenten in de meeste gevallen beseften dat ze een collocatie of een vaste verbinding in een zin zouden moeten gebruiken, maar ze konden niet altijd het juiste woord of de juiste combinatie van woorden uit hun geheugen oproepen. Als gevolg hiervan verzonnen ze combinaties die qua vorm op bestaande Nederlandse collocaties lijken maar helaas niet acceptabel zijn als correcte vertaling. De collocaties die door de studenten werden gebruikt, waren in veel gevallen grammaticaal en lexicaal gezien minder complex dan die van de moedertaalspreker.

Aanbeveling voor het onderwijs: naast receptieve kennis van collocaties moet er meer aandacht besteed worden aan de productie van vaste verbindingen. Hierbij kan men aan invuloefeningen denken waarbij een deel van een collocatie aangevuld moet worden, of aan oefeningen waarbij leerders uit meerdere antwoorden kunnen kiezen.

In vertaaloefeningen voor toekomstige tolken kunnen de contrastieve verschillen tussen de moedertaal en de vreemde taal expliciet onder de aandacht worden gebracht, waardoor niet alleen collocaties maar ook grammaticale verschillen tussen de twee talen geoefend kunnen worden.

\section{Bibliografie}

Bot, K. de, Lowie, W., en Verspoor, M. (2005). Second language acquisition. London/New York: Routledge. https://doi.org/10.4324/9780203446416

Durrant, P., en Schmitt, N. (2009). To What Extent Do Native and Non-Native Writers Make Use of Collocations? In: International Review of Applied Linguistics in Language Teaching (IRAL), 47(2), 157-177. https://doi.org/10.1515/iral.2009.007

Ellis, N. C., Simpson-Vlach, R., \& Maynard, C. (2008). Formulaic Language in Native and Second Language Speakers: Psycholinguistics, Corpus Linguistics, and TESOL. TESOL Quarterly, 42(3), 375-396. https://doi.org/10.1002/j.1545-7249.2008.tb00137.x

F. Csizmadia, Erzsébet (2020) Mit kell tudnia egy blattolónak? Avagy miből áll a blattolói kompetencia? In: Szabó, Csilla; Bakti, Mária (Reds.) Iránytü a tolmácsolás oktatásához: A kompetenciafejlesztés új fókuszai. Szeged: JGYF Kiadó. 37-58.

González Fernández, B., \& Schmitt, N. (2015). How much collocation knowledge do L2 learners have?: The effects of frequency and amount of exposure. ITL - International Journal of Applied Linguistics, 166(1), 94-126. https://doi.org/10.1075/itl.166.1.03fer

Hein, E., en Verlangen, R. (2020). Veerkracht en presteren onder druk tijdens Covid-19. Ambulancezorg, 41(2), 36-42. 
Hein, E. (2018). Presteren onder druk: https://www.erikheinacademy.com/wpcontent/uploads/2018/10/Presteren-onder-druk.pdf

Herschensohn, J. R., en Young-Scholten, M. (Reds.). (2013). The Cambridge handbook of second language acquisition. Cambridge University Press. https://doi.org/10.1017/CBO9781139051729

Kleijn, P. de (1988). Kennis van vaste verbindingen: belangrijk en moeilijk. Neerlandica Extra Muros 50, 2-7.

Mollay, E. (1989). Overeenkomsten en verschillen tussen Nederlandse en Hongaarse vaste woordverbindingen. In: Colloquium Neerlandicum 10. (1988) Handelingen Tiende Colloquium Neerlandicum. Colloquium van docenten in de neerlandistiek aan buitenlandse universiteiten Internationale Vereniging voor Neerlandistiek. 179-186. https://www.dbnl.org/tekst/_han001198801_01/_han001198801_01_0021.phpNesselhauf

Nesselhauf, N. (2003). The Use of Collocations by Advanced Learners of English and Some Implications for Teaching. In: Applied Linguistics, 24(2), 223-242. https://doi.org/10.1093/applin/24.2.223

Siyanova-Chanturia, A., en Spina, S. (2015). Investigation of Native Speaker and Second Language Learner Intuition of Collocation Frequency. Language Learning, 65(3), 533-562. https://doi.org/10.1111/lang.12125

Schmitt, N. (2000). Vocabulary in language teaching. Cambridge: Cambridge University Press. Veresné Valentinyi, Klára, A blattolás a tolmács kompetenciáinak fejlesztésében In: Szabó, Csilla; Bakti, Mária (Reds.) Iránytü a tolmácsolás oktatásához: A kompetenciafejlesztés új fókuszai. Szeged: JGYF Kiadó. 123-140. 


\section{Bijlage 1}

8.1 Originele Hongaarse tekst

HÁNY BOLYGó KELLENE AHHOZ, HOGY MINDENKI ÚGY ÉLHESSEN, MINT TE?

Mi, emberek abból élünk, amit a természet nyújt. Ha azonban a világon mindenki olyan életmódot folytatna, mint az európaiak, akkor május 10-én lépnénk át azt a dátumot, amikor az emberiség fogyasztása túllépi azt a szintet, amit a Föld egy év alatt képes újratermelni.

A Global Footprint Network minden évben nyilvánosságra hozza a túlfogyasztás világnapjának aktuális dátumát, amely tavaly augusztus 1-jére esett.

(https://divany.hu/vilagom/2019/05/10/tulfogyasztas-napja-2019/)

\subsection{Nederlandse vertaling met vertaalopties}

HOEVEEL PLANETEN ZOUDEN WE NODIG HEBBEN/HEBBEN WE NODIG ALS IEDEREEN ZOU WILLEN LEVEN ZOALS JIJ? / ALS WE IEDEREEN EEN LEVEN ZOUDEN GUNNEN ZOALS DAT VAN JOU? / OM IEDEREEN TE KUNNEN LATEN LEVEN ZOALS JIJ?

Wij mensen leven van (datgene) wat de natuur ons biedt. Maar als de hele wereldbevolking zou leven zoals de Europeanen / Maar als mensen er overal ter wereld dezelfde levensstijl op na zouden houden als wij hier in Europa, / Maar als men overal ter wereld zou leven zoals wij hier in Europa, dan zouden we al op 10 mei as. de datum bereiken waarop het totale verbruik van de mensheid het niveau zou overschrijden van wat de aarde in één jaar kan produceren en/of incasseren/ verwerken.

Het Global Footprint Network publiceert elk jaar de actuele/nieuwe datum van de werelddag van de overconsumptie /de nieuwe datum van de globale overconsumptie, die vorig jaar op 1 augustus viel. 


\section{Bijlage 2}

\begin{tabular}{|c|c|c|c|c|c|c|c|c|c|c|c|c|c|}
\hline naam & kellene hozzá & $\begin{array}{l}\text { életmód } \\
\text { ot folytat }\end{array}$ & $\begin{array}{l}\text { abból } \\
\text { élünk }\end{array}$ & a világon & $\begin{array}{l}\text { dátumot } \\
\text { átlép }\end{array}$ & szintet túllép & minden évben & $\begin{array}{l}\text { nyilvános } \\
\text { ságra hoz }\end{array}$ & $\begin{array}{c}\text { tavaly } \\
\text { (dátum)r } \\
\text { a esett }\end{array}$ & $\begin{array}{l}\text { hátralévő } \\
\text { részében }\end{array}$ & $\begin{array}{c}\text { erőforrás } \\
\text { t hitelez }\end{array}$ & $\begin{array}{l}\text { fény } \\
\text { derül }\end{array}$ & $\begin{array}{l}\text { mikor } \\
\text { van }\end{array}$ \\
\hline Student 1 & $\begin{array}{l}\text { zouden we } \\
\text { nodig hebben }\end{array}$ & $\begin{array}{l}\text { op die } \\
\text { manier te } \\
\text { kunnen } \\
\text { leven }\end{array}$ & leven van & ter wereld & $\begin{array}{l}\text { datum } \\
\text { doorlopen* }\end{array}$ & $\begin{array}{l}\text { een grens of } \\
\text { niveau } \\
\text { doorgaat* }\end{array}$ & elk jaar & $\begin{array}{l}\text { bekend } \\
\text { maken }\end{array}$ & \begin{tabular}{|l} 
in het \\
vorige \\
jaar op ... \\
was
\end{tabular} & $\begin{array}{l}\text { volgende } \\
\text { tijd van } \\
\text { het jaar* }\end{array}$ & $\begin{array}{l}\text { krachtbro } \\
\text { nnen } \\
\text { uitlenen }\end{array}$ & $\begin{array}{l}\text { aan het } \\
\text { licht } \\
\text { komen }\end{array}$ & $\begin{array}{l}\text { wanneer } \\
\text { de dag is }\end{array}$ \\
\hline Student 2 & $\begin{array}{l}\text { moeten we } \\
\text { hebben }\end{array}$ & $\begin{array}{l}\text { een leven } \\
\text { method } \\
\text { hebben* }\end{array}$ & $\begin{array}{l}\text { leven } \\
\text { vanuit** }\end{array}$ & & $0 \begin{array}{l}\text { de datum } \\
\text { stappen } \\
\text { wanneer* }\end{array}$ & & in een jaar & $\begin{array}{l}\text { neemt in } \\
\text { publici* }\end{array}$ & \begin{tabular}{|l|} 
volgende \\
jaar in de \\
eerst of \\
August \\
was*
\end{tabular} & $\begin{array}{l}\text { de rest } \\
\text { van de } \\
\text { jaar* }\end{array}$ & $\begin{array}{l}\text { geeft de } \\
\text { brommen } \\
\text { aan de } \\
\text { mensen }\end{array}$ & $\begin{array}{l}\text { informatie } \\
\text { hebben }\end{array}$ & $\begin{array}{l}\text { wanneer } \\
\text { de dag is }\end{array}$ \\
\hline Student 3 & zijn er nodig & \begin{tabular}{|l|} 
levensstijl \\
volgen
\end{tabular} & leven van & in de wereld & $\begin{array}{l}\text { de datum } \\
\text { overlopen* }\end{array}$ & $\begin{array}{l}\text { met het niveau } \\
\text { overgaan* }\end{array}$ & elke jaar* & \begin{tabular}{|l} 
rapport \\
geven over
\end{tabular} & $\begin{array}{l}\text { vorig jaar } \\
\text { op ... } \\
\text { plaatsvon } \\
\text { d }\end{array}$ & \begin{tabular}{|l|} 
de laatste \\
delen van \\
de jaar*
\end{tabular} & \begin{tabular}{|l|} 
grondstoff \\
en \\
verlenen \\
voor
\end{tabular} & $\begin{array}{l}\text { het werd } \\
\text { duidelijk }\end{array}$ & $\begin{array}{l}\text { wanneer } \\
\text { de dag is }\end{array}$ \\
\hline Student 4 & nodig hebben & \begin{tabular}{|l|} 
levensstijl \\
leven*
\end{tabular} & leven van & 0 & 0 & \begin{tabular}{|l} 
lonsumtie \\
opgebruiken of \\
zo
\end{tabular} & elk jaar & $\begin{array}{l}\text { brengt de } \\
\text { datum ...* }\end{array}$ & $\begin{array}{l}\text { vorig jaar } \\
\text { op ... is } \\
\text { gevallen }\end{array}$ & $\begin{array}{l}\text { na deze } \\
\text { datum }\end{array}$ & $\begin{array}{l}\text { lenen } \\
\text { aan** }\end{array}$ & $\begin{array}{l}\text { het is } \\
\text { gebleken }\end{array}$ & $\begin{array}{l}\text { wanneer ... } \\
\text { is }\end{array}$ \\
\hline Student 6 & nodig zijn voor & \begin{tabular}{|l} 
leven \\
volgen
\end{tabular} & leven van & & \begin{tabular}{|l|} 
de dag dat \\
de \\
0 overconsum \\
ptie \\
markeert \\
\end{tabular} & & elke jaar & publiceert & $\begin{array}{l}\text { het laatste } \\
\text { jaar was } 1 \\
\text { augustus }\end{array}$ & $\begin{array}{l}\text { in de } \\
\text { volgende } \\
\text { maanden }\end{array}$ & \begin{tabular}{|l} 
heeft \\
energiebro \\
nnen \\
geloond*
\end{tabular} & $\begin{array}{l}\text { informatie } \\
\text { krijgen }\end{array}$ & $\begin{array}{l}\text { wanneer } \\
\text { de dag is }\end{array}$ \\
\hline Student 7 & 0 & 0 & $\begin{array}{l}\text { leven } \\
\text { waarvoor* }\end{array}$ & op de wereld & $\begin{array}{l}\text { de datum } \\
\text { toetreden } \\
\text { wanneer* }\end{array}$ & $\begin{array}{l}\text { de lijn of } \\
\text { draad... zoiets * } \\
\text { (lacht) }\end{array}$ & iedere jaar* & $\begin{array}{l}\text { brengt de } \\
\text { datum } \\
\text { van* }\end{array}$ & \begin{tabular}{|l} 
vorige \\
jaar* in \\
augustus \\
was \\
\end{tabular} & \begin{tabular}{|l|} 
in de \\
voorlopige \\
deel*
\end{tabular} & \begin{tabular}{|l} 
leent \\
krachts br \\
onnen \\
voor* \\
\end{tabular} & $\begin{array}{l}\text { kwamen } \\
\text { we tot } \\
\text { weten* }\end{array}$ & \begin{tabular}{|l}
$\begin{array}{l}\text { wanneer } \\
\text { de dag } \\
\text { gebeurt* } \\
\text { (lacht) }\end{array}$ \\
\end{tabular} \\
\hline Student 8 & hoeven & $\begin{array}{l}\text { zulke } \\
\text { levensstijl } \\
\text { heeft* }\end{array}$ & leven van & op de wereld & \begin{tabular}{|l} 
bereikt de \\
datum \\
wanneer
\end{tabular} & $\begin{array}{l}\text { te veel } \\
\text { gebruiken }\end{array}$ & in elke jaar* & publiceren & $\begin{array}{l}\text { was vorige } \\
\text { jaar op ...* }\end{array}$ & $\begin{array}{l}\text { rest van } \\
\text { de jaar* }\end{array}$ & \begin{tabular}{|l|} 
verleende \\
de \\
bronnen \\
voor* \\
\end{tabular} & $\begin{array}{l}\text { komen we } \\
\text { weten* }\end{array}$ & $\begin{array}{l}\text { wanneer } \\
\text { is de dag* }\end{array}$ \\
\hline
\end{tabular}

